\title{
Pengaruh Kepemimpinan Transformasional Terhadap Kinerja Pegawai Pada BPMPT Provinsi Jawa Barat Indra Saftara*
}

Sekolah Tinggi Pariwisata Bandung, Indonesia Email: indrasaftara@stp-bandung.ac.id

\begin{abstract}
The main problem in this research is the performance of employees of Investment Board and Integrated Licensing (BPMPT) West Java Province felt very less. The problem is caused by the absence of optimal transformational leadership. The approach used in this research is descriptive method of analysis that describes social phenomena by examining the influence of Transformational Leadership $(\mathrm{X})$ on Employee Performance (Y). This research uses a quantitative analysis technique through path analysis which is intended to know the influence of variables of Transformational Leadership toward Employee Performance, either simultaneously or partially. The results showed that Transformational Leadership affects Employee Performance on the Investment Board and Integrated Licensing (BPMPT) of West Java Province. The simultaneous effect of transformational leadership variables on employee performance was $82 \%$. The value is strong enough. While other influences that are not examined or epsilon affect employee performance of $17.2 \%$. Partially, Transformational Leadership is tested in influencing employee performance that is covering an aspect of ideal influence equal to $6,5 \%$, inspirational aspect motivation $21 \%$, aspect of intellectual simulation equal to $27,4 \%$, aspect of individual consideration $27,9 \%$ and other variable $17,2 \%$. The conclusion that transformational leadership is a very important factor in influencing the performance of the employees of the Investment and Investment Permit (BPMPT) of West Java Province. Optimize the performance of key personnel is done through transformational leadership variables. The results of this study can be concluded that the transformational leadership either simultaneously or partially affect the performance of employees of the Investment and Integrated Licensing Agency (BPMPT) West Java Province.
\end{abstract}

Keywords: Employee Performance, Transformational Leadership, BPMPT, West Java.

\begin{abstract}
Abstrak
Masalah utama dalam penelitian ini adalah kinerja pegawai Badan Penanaman Modal dan Perizinan Terpadu (BPMPT) Provinsi Jawa Barat dirasakan sangat kurang. Masalahnya disebabkan oleh tidak adanya kepemimpinan transformasional yang optimal. Pendekatan yang digunakan dalam penelitian ini adalah metode deskriptif analisis yang menggambarkan fenomena sosial dengan menguji pengaruh Kepemimpinan Transformasional (X) terhadap Kinerja Karyawan (Y). Penelitian ini menggunakan teknik analisis kuantitatif melalui analisis jalur yang dimaksudkan untuk mengetahui pengaruh variabel Kepemimpinan Transformasional terhadap Kinerja Karyawan, baik secara simultan maupun parsial. Hasil penelitian menunjukkan bahwa Kepemimpinan Transformasional mempengaruhi Kinerja Karyawan pada Badan Investasi dan Perizinan Terpadu (BPMPT) Provinsi Jawa Barat. Efek simultan dari variabel kepemimpinan transformasional pada kinerja karyawan adalah $82 \%$. Nilainya cukup kuat. Sedangkan pengaruh lain yang tidak diteliti atau epsilon mempengaruhi kinerja karyawan sebesar $17,2 \%$. Secara parsial, Kepemimpinan Transformasional diuji dalam mempengaruhi kinerja karyawan yang meliputi aspek pengaruh ideal sebesar 6,5\%, motivasi aspek inspirasional $21 \%$, aspek simulasi intelektual sebesar $27,4 \%$, aspek pertimbangan individu $27,9 \%$ dan variabel lainnya $17,2 \%$. Kesimpulannya bahwa kepemimpinan transformasional merupakan faktor yang sangat penting dalam mempengaruhi kinerja pegawai pada Izin Investasi dan Investasi (BPMPT) Provinsi Jawa Barat. Mengoptimalkan kinerja personel kunci dilakukan melalui variabel kepemimpinan transformasional. Hasil penelitian ini dapat disimpulkan bahwa kepemimpinan transformasional baik secara simultan atau parsial mempengaruhi kinerja pegawai Badan Penanaman Modal dan Perizinan Terpadu (BPMPT) Provinsi Jawa Barat.
\end{abstract}

Kata Kunci: Kinerja Karyawan, Kepemimpinan Transformasional, BPMPT, Jawa Barat 


\section{A. PENDAHULUAN}

Sumber daya manusia merupakan salah satu faktor yang perlu dikelola dengan baik oleh organisasi. Dimana pengelolaan sumber daya manusia hams dilakukan secara profesional agar dihasilkan sumber daya manusia yang kompeten sehingga nantinya dapat meningkatkan kinerja dari individu dan organisasi. Namun kunci dari keberhasilan dalam pengelolaan tersebut terutama bagi para pegawai salah satunya adalah bagaimana kepemimpinan yang ada dalam organisasi. Dalam proses menciptakan kinerja yang tinggi, kepemimpinan dari seorang pemimpin memiliki peran yang sangat krusial.

Kepemimpinan menggambarkan hubungan antara pemimpin dengan yang dipimpin dan bagaimana seorang pemimpin mengarahkan yang dipimpin. Pemimpin dapat mempengaruhi perilaku para bawahannya melalui pendekatan dalam mengelola sumber daya manusia. Untuk itu organisasi memerlukan seorang pemimpin yang efektif dan mampu menjadi motor penggerak perubahan dalam organisasi dan pemimpin yang mampu menetapkan sasaran-sasaran khusus, memonitor perkembangan, dan mengidentifikasi penghargaan yang diterima karyawan apabila sasaran yang diinginkan dapat tercapai.

Keempat aspek kepemimpinan transfonnasional tersebut mendorong karyawan untuk bekerja lebih keras, meningkatkan produktifitas kerja, memiliki moril kerja serta kepuasan ketja yang lebih tinggi, meninggikan efektifitas organisasi, meminimalkan perputaran karyawan, menurunkan tingkat ketidakhadiran, dan memiliki kemampuan menyesuaikan diri secara organisasional yang lebih tinggi".

Demikian pula halnya dengan insitusi Badan Penanaman Modal dan Perizinan Terpadu (BPMPT) Provinsi Jawa Barat, hams memperhatikan, menjaga, dan mengembangkan sumber daya manusianya dengan baik. BPMPT Provinsi Jawa Barat sebagai Lembaga Penanaman Modal dan Perizinan Terpadu mempunyai visi "Pelayanan Perizinan Yang Andal Dan Profesional". Adapun BPMPT itu sendiri merupakan penggabungan dari BPPT dan BKPMD, sehingga untuk urusan organisasi yang mengurusi perizinan dan pelayanan ini dibagi menjadi dua kubu. Akibat dua kubu inilah terjadi egosentris diantara kedua kubu tersebut dan para karyawan BPMPT itu sendiri di dominasi oleh pimpinan BKPMD.

Agar tugas pokok dan fungsi BPMPT Provinsi Jawa Barat tersebut dapat berjalan dengan baik maka hams di dukung oleh kepemimpinan yang efektif dan mampu mempengaruhi serta mengendalikan bawahan agar mencapai tujuan. Dan untuk mencapai kinerja pegawai yang tinggi di BPMPT Provinsi Jawa Barat, hal tersebut tentu dipengaruhi oleh faktor kepemimpinan yang diterapkan dalam organisasi. Dengan adanya penerapan kepemimpinan yang baik dan efektif maka diharapkan kinerja dari masing-masing pegawai di lingkungan BPMPT Provinsi Jawa Barat akan meningkat.

\section{B. METODE PENELITIAN}

Metode penelitian merupakan cara ilmiah yang digunakan untuk mendapatkan data dengan tujuan dan kegunaan tertentu (Sugiyono, 2010:1). Dimana cara ilmiah ini berarti kegiatan itu dilandasi oleh ciri-ciri keilmuan yang rasional, empiris dan sistematis. Dengan cara ini diharapkan data-data yang akan didapatkan oleh peneliti menjadi lebih obyektif, valid dan reliabel. Penelitian merupakan proses yang sistematis. Tiap tahapan merupakan bagian yang menentukan tahapan selanjutnya sehingga harus dilalui secara cermat dan teliti.

Teori-teori yang sudah ada merupakan pijakan untuk melakukan penelitian dan menjadikan dasar bagi setiap langkah dalam proses penelitian yang dilakukan.

Metode yang digunakan untuk penelitian ini adalah metode deskriptif analisis. Maksudnya adalah dengan tujuan untuk memberikan gambaran tentang sesuatu dan untuk lebih memahami 
gejala atau pennasalahan tertentu, sehingga pada akhir penelitian ini tidak hanya untuk menguji hasil penelitian tetapi menghasilkan suatu pemahaman mendalam secara fenomenologis yang akan diteliti untuk menghasilkan rekomendasi perbaikan dalam hal penerapan kepemimpinan transformasional di BPMPT Provinsi Jawa Barat dan konsep yang diajukan. Berdasarkan pijakan tersebut, peneliti melakukan penelitian kuantitatif.

\section{HASIL DAN ANALISIS}

Pada bagian ini akan dibahas mengenai hasil penelitian dan pembahasan, pada hasil penelitian membahas mengenai data yang di dapat dari lapangan, adapun variabel penelitian yang diamati terdiri dari dua variabel, yaitu variabel kepemimpinan transformasional sebagai variabel bebas yang diberi simbol X dan kinerja pegawai sebagai variabel tidak bebas yang diberi simbol Y. Penelitian ini dilakukan dengan cara menganalisis variabel kepemimpinan transfonnasional yang diperkirakan mempunyai pengaruh besar terhadap kinerja pegawai, rangkaian penelitian yang dilakukan sebagai suatu studi kasus di BPMPT Provinsi Jawa Barat.

Pada penelitian ini yang dijadikan sebagai unit analisis adalah para pegawai di pertimbangan yang bersifat individual BPMPT Provinsi Jawa Barat, dengan keseluruhan jumlah pegawai sebanyak 53 orang diambil sebagai responden. Selanjutnya kepada responden tersebut di ajukan pernyataanpernyataan dalam angket yang merupakan penjabaran dari indikator- indikator variabel kepemimpinan transformasional dan variabel kinerja pegawai.

Tabel 1. Hash U Validitas Variabel Kepemimninan transformasional $(\mathrm{X})$

\begin{tabular}{|c|c|c|c|}
\hline Item & $\mathrm{r}$ & $\mathrm{r}$ tabel & Keputusan \\
\hline 1 & 0.390 & 0.388 & Valid \\
\hline 2 & 0.797 & 0.388 & Valid \\
\hline 3 & 0.675 & 0.388 & Valid \\
\hline 4 & 0.734 & 0.388 & Valid \\
\hline 5 & 0.435 & 0.388 & Valid \\
\hline 6 & 0.708 & 0.388 & Valid \\
\hline 7 & 0.665 & 0.388 & Valid \\
\hline 8 & 0.567 & 0.388 & Valid \\
\hline 9 & 0.473 & 0.388 & Valid \\
\hline 10 & 0.617 & 0.388 & Valid \\
\hline 11 & 0.735 & 0.388 & Valid \\
\hline 12 & 0.660 & 0.388 & Valid \\
\hline & \multicolumn{2}{|c|}{ Sumber : Hasil Pengolahan Data, Januari 2016 } \\
\hline
\end{tabular}

Tabel 2. Hasil Uii Validitas Variabel Y (Kineria Pegawai

\begin{tabular}{|c|c|c|c|}
\hline Item & $\mathrm{r}$ & $\mathrm{r}$ tabel & Keputusan \\
\hline 13 & 0.636 & 0.388 & Valid \\
\hline 14 & 0.477 & 0.388 & Valid \\
\hline 15 & 0.564 & 0.388 & Valid \\
\hline 16 & 0.437 & 0.388 & Valid \\
\hline 17 & 0.622 & 0.388 & Valid \\
\hline 18 & 0.644 & 0.388 & Valid \\
\hline 19 & 0.616 & 0.388 & Valid \\
\hline 20 & 0.667 & 0.388 & Valid \\
\hline 21 & 0.572 & 0.388 & Valid \\
\hline 22 & 0.525 & 0.388 & Valid \\
\hline 23 & 0.389 & 0.388 & Valid \\
\hline 24 & 0.399 & 0.388 & Valid \\
\hline
\end{tabular}




\begin{tabular}{|l|l|l|l|}
\hline 25 & 0.354 & 0.388 & Valid \\
\hline 26 & 0.399 & 0.388 & Valid \\
\hline 27 & 0.553 & 0.388 & Valid \\
\hline \multicolumn{4}{|c|}{ Sumber : Hasil Pengolahan Data, Januari 2016 } \\
\hline
\end{tabular}

\section{Deskripsi Hasil Penelitian}

Sebagaimana telah diuraikan sebelunmya bahwa variabel penelitian ini terdiri dari dua variabel, yaiht variabel kepemimpinan transformasional sebagai variabel bebas yang diberi simbol X dan dan kinerja pegawai sebagai variabel tidak bebas, yang diberi simbol Y. Pcnelitian ini dilakukan dengan cara menganalisis variabel kepemimpinan transformasional yang diperkirakan mempunyai pengaruh besar terhadap kinerja pegawai BPMPT Provinsi Jawa Barat.

Variabel kepemimpinan transformasional ini terdiri dari dimensi pengaruh yang ideal, motivasi yang inspirasional, stimulasi intelektual serta pertimbangan yang bersifat individual. Dalam hubungannya dengan kinerja pegawai. Sedangkan variabel kinerja pegawai sendiri dilihat dari dimensi kualitas kerja, ketepatan waktu, inisiatif, kemampuan dan komunikasi.

\section{Variabel Kepemimpinan Transformasional (X)}

Aspek Pengaruh Yang Ideal

Tabel 3. Total Skor Aspek pengaruh yang ideal

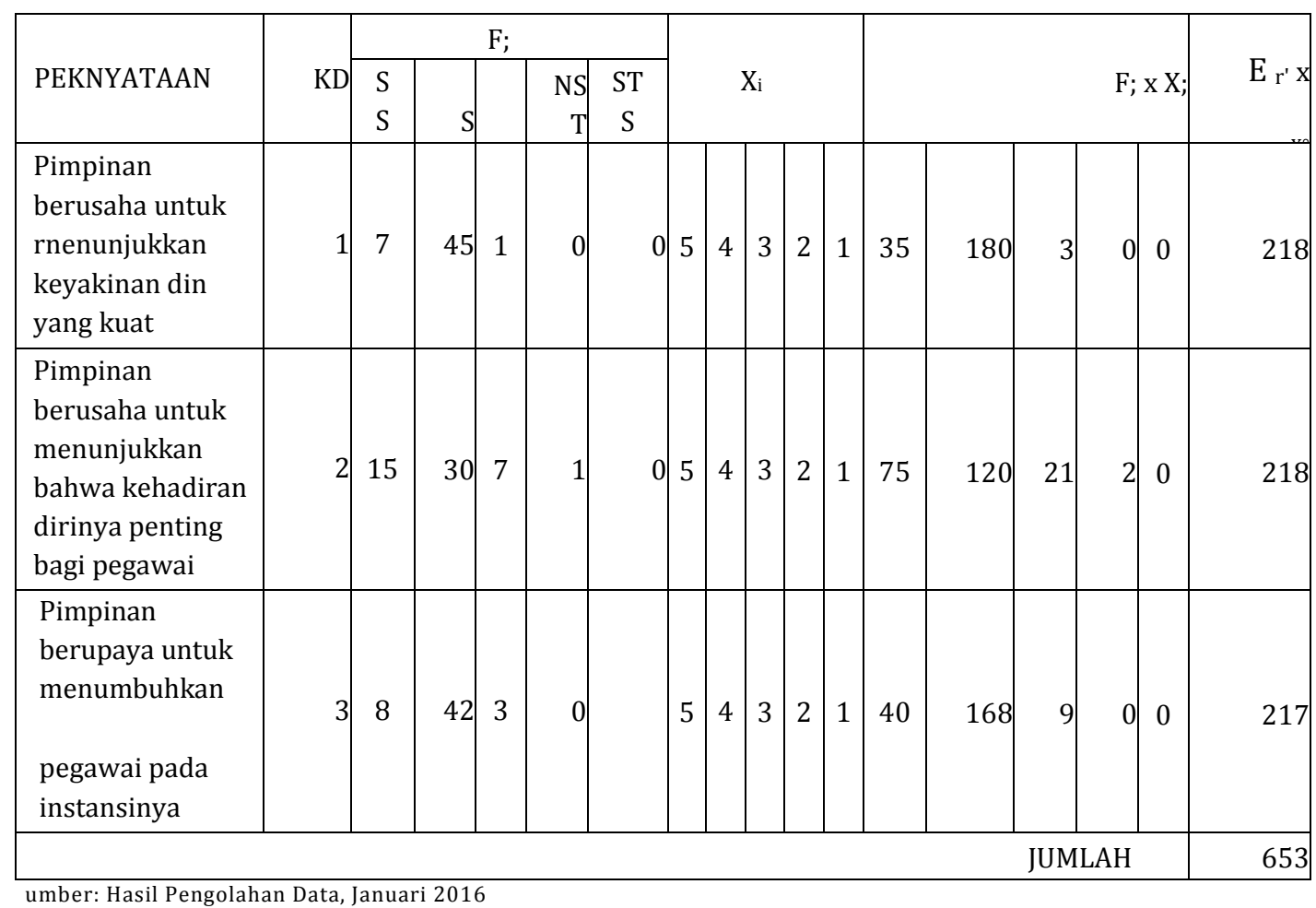

Aspek Motivasi yang inspirasional

Tabel 4. Total Skor Aspek motivasi yang inspirasional 


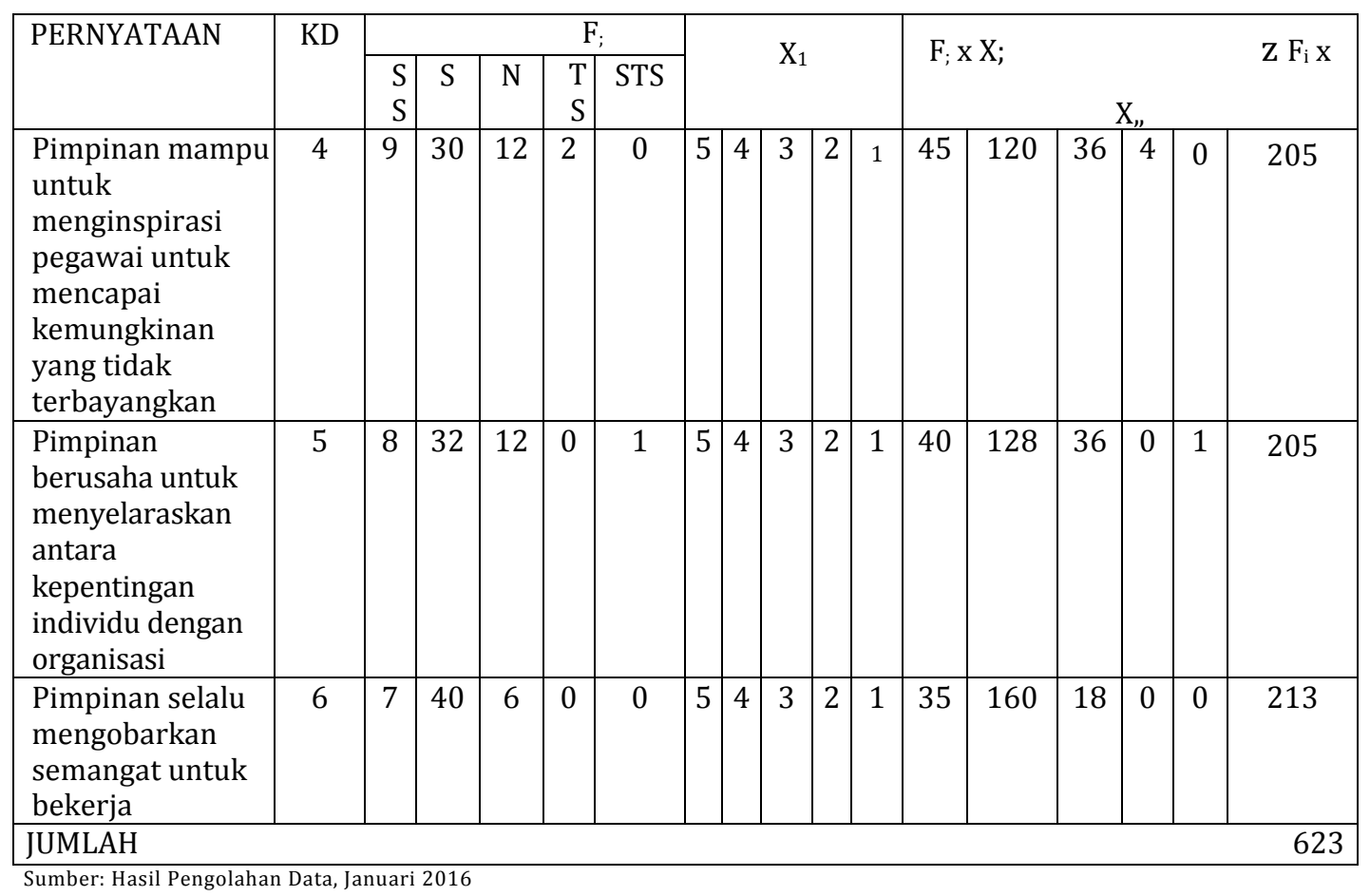

\section{Aspek Stimulasi intelektual}

Tabel 5. Total Skor Aspek Stimulasi intelektual

\begin{tabular}{|c|c|c|c|c|c|c|c|c|c|c|c|c|c|c|c|c|c|}
\hline \multirow{2}{*}{$\begin{array}{c}\text { PERNYAT } \\
\text { A- } \\
\text { AN }\end{array}$} & \multirow[b]{2}{*}{ K } & \multicolumn{5}{|c|}{$\mathrm{F}$; } & & \multirow{2}{*}{\multicolumn{4}{|c|}{$\mathrm{X}$}} & \multirow{2}{*}{\multicolumn{5}{|c|}{$\mathrm{F} ; \mathrm{xXi}$}} & \multirow[b]{2}{*}{$\sim \mathrm{F}_{1} \mathrm{X}^{\mathrm{X}^{\prime \prime}}$} \\
\hline & & SS & & SNS & $\mathrm{T}$ & STS & & & & & & & & & & & \\
\hline $\begin{array}{c}\text { selaku } \\
\text { mendorong } \\
\text { untuk } \\
\text { memanfaatk } \\
\text { an imajinasi } \\
\text { pegawai }\end{array}$ & 7 & 12 & 9 & 12 & 0 & 0 & 5 & 4 & 3 & 2 & 1 & 60 & 16 & 36 & 0 & 0 & 212 \\
\hline $\begin{array}{c}\text { Pimpinan } \\
\text { sclalu } \\
\text { mendorong } \\
\text { institusi yang } \\
\text { dipadu } \\
\text { dengan } \\
\text { logika } \\
\end{array}$ & 8 & 7 & 9 & 18 & 1 & 0 & 5 & 4 & 3 & 2 & 1 & 35 & $\begin{array}{c}11 \\
6\end{array}$ & 54 & 2 & 0 & 207 \\
\hline Pimpinan & 9 & 1 & 2 & 25 & 0 & 0 & 5 & 4 & 3 & 2 & 1 & 5 & 10 & 75 & 0 & 0 & 188 \\
\hline
\end{tabular}




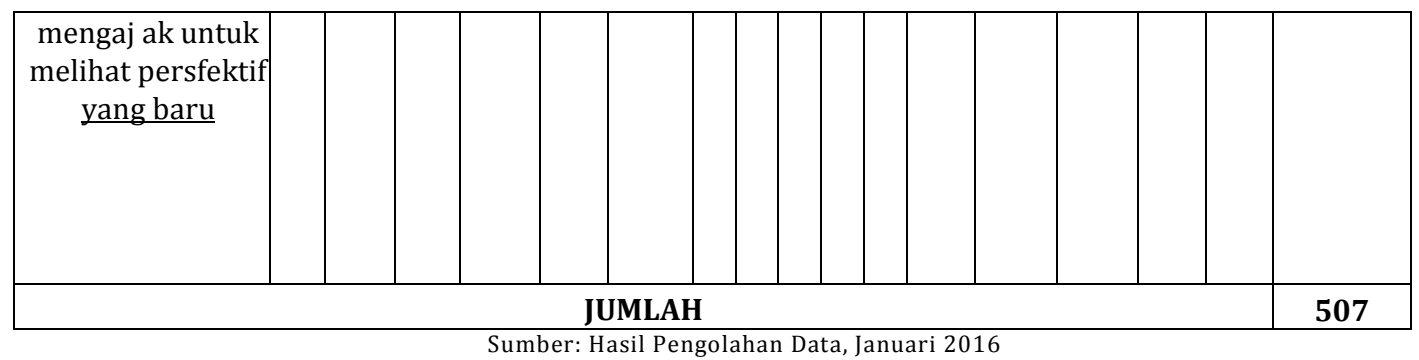

Aspek Pertimbangan yang bersifat individual

Tabel 6. Total Skor Aspek pertimbangan yang bersifat individual

\begin{tabular}{|c|c|c|c|c|c|c|c|c|c|c|c|c|c|c|c|c|c|}
\hline \multirow{2}{*}{$\begin{array}{c}\text { PERNYATA } \\
- \\
\end{array}$} & \multirow[b]{2}{*}{$\mathrm{K}$} & \multicolumn{5}{|c|}{ F; } & \multirow{2}{*}{\multicolumn{5}{|c|}{$\mathrm{X}$; }} & \multirow{2}{*}{\multicolumn{5}{|c|}{ F; x X; }} & \multirow{2}{*}{ L F; $x$} \\
\hline & & SS & & SNS & $\mathrm{T}$ & STS & & & & & & & & & & & \\
\hline $\begin{array}{l}\text { mengidentifik } \\
\text { asi kebutuhan } \\
\text { individu } \\
\text { pegawai }\end{array}$ & 0 & 7 & 6 & 9 & 1 & 0 & 5 & 4 & 3 & 2 & 1 & 35 & 4 & 27 & 2 & 0 & 208 \\
\hline $\begin{array}{c}\text { Pimpinan } \\
\text { memberikan } \\
\text { kesempatan } \\
\text { untuk belajar } \\
\text { kepada } \\
\text { pegawainya }\end{array}$ & 1 & 9 & 0 & 13 & 1 & I 0 & 5 & 4 & 3 & 2 & 1 & 45 & 17 & 39 & 2 & 0 & 206 \\
\hline $\begin{array}{c}\text { Pimpinan } \\
\text { selalu } \\
\text { berttsaha } \\
\text { untuk } \\
\text { memberdayak } \\
\text { an } \\
\text { bawahannya }\end{array}$ & 2 & 7 & 9 & 7 & 0 & 0 & 5 & 4 & 3 & 2 & 1 & 35 & 15 & 21 & 0 & 0 & 212 \\
\hline & & & & & & JMLA & & & & & & & & & & & 626 \\
\hline
\end{tabular}

\section{Variabel Kinerja pegawai}

\section{Dimensi Kualitas Kerja}

Tabel 7. Total Skor Dimensi Kualitas kerja

\begin{tabular}{|c|c|c|c|c|c|c|c|c|c|c|c|c|c|c|c|c|c|}
\hline \multirow[t]{2}{*}{ PERNYATAAN } & \multirow[t]{2}{*}{ KD } & \multicolumn{5}{|c|}{$\mathrm{F} ;$} & \multirow{2}{*}{\multicolumn{5}{|c|}{$\mathrm{X}$}} & \multirow{2}{*}{\multicolumn{5}{|c|}{$\mathrm{F}_{\mathrm{iX} X}$}} & \multirow{2}{*}{$\begin{array}{c}\text { Y F1 x } \\
X_{n}\end{array}$} \\
\hline & & & SSN & & $\mathrm{T}$ & STS & & & & & & & & & & & \\
\hline $\begin{array}{c}\text { Ketelitian bekerja } \\
\text { diperlukan dalam } \\
\text { menyelesaikan } \\
\text { suatu pekerjaan }\end{array}$ & 13 & 8 & $\begin{array}{l}3 \\
7\end{array}$ & 8 & 0 & 0 & 5 & 4 & 3 & 2 & 1 & 40 & $\begin{array}{l}14 \\
8\end{array}$ & 24 & 0 & 0 & 212 \\
\hline $\begin{array}{c}\text { Hasil kerja } \\
\text { pegawai sudah }\end{array}$ & 14 & 4 & 3 & 1 & 0 & 0 & 5 & 4 & 3 & 2 & 1 & 20 & 14 & 36 & 0 & 0 & 204 \\
\hline
\end{tabular}




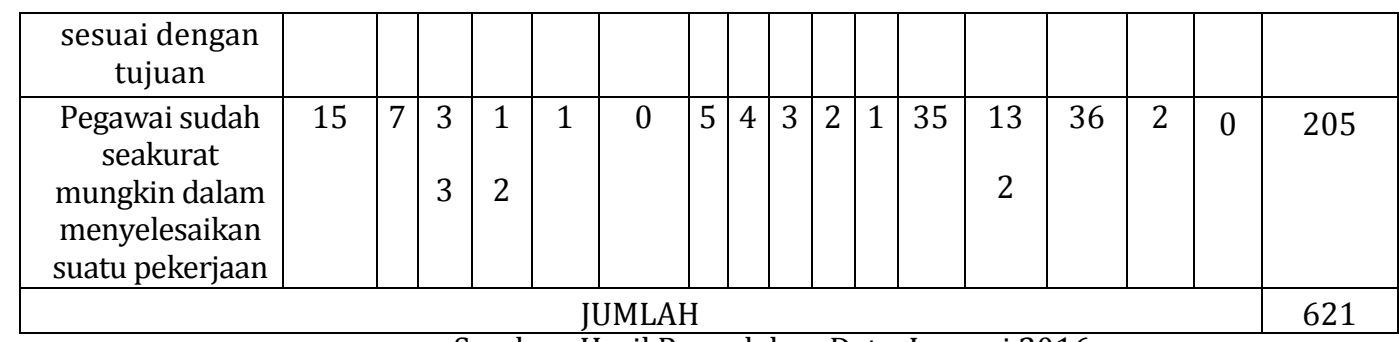

Sumber: Hasil Pengolahan Data, Januari 2016

\section{Dimensi Ketepatan Waktu}

Tabel 8. Total Skor Dimensi Ketepatan waktu

\begin{tabular}{|c|c|c|c|c|c|c|c|c|c|c|c|c|c|c|c|c|c|}
\hline \multirow{2}{*}{$\begin{array}{l}\text { PERNYATA- } \\
\text { AN }\end{array}$} & \multirow{2}{*}{$\mathrm{K}$} & \multicolumn{5}{|c|}{$F^{\prime}$} & \multirow{2}{*}{\multicolumn{5}{|c|}{ X; }} & \multirow{2}{*}{\multicolumn{5}{|c|}{ F; x X; }} & \multirow[b]{2}{*}{$\sim F ; x$} \\
\hline & & & & & $\mathrm{T}$ & ST & & & & & & & & & & & \\
\hline $\begin{array}{l}\text { Pegawal selalu } \\
\text { datang tepat } \\
\text { waktu }\end{array}$ & 6 & 3 & 4 & 7 & 1 & 0 & 5 & 4 & 3 & 2 & 1 & 15 & 8 & 21 & 2 & 0 & 206 \\
\hline $\begin{array}{c}\text { Waktu pulang } \\
\text { untuk semua } \\
\text { pegawai sama }\end{array}$ & 1 & 5 & 4 & 14 & 0 & 0 & 5 & 4 & 3 & 2 & 1 & 25 & 6 & 42 & 0 & 0 & 203 \\
\hline $\begin{array}{l}\text { Pegawai selalu } \\
\text { hadir }\end{array}$ & 1 & 5 & 3 & 12 & 0 & 0 & 5 & 4 & 3 & 2 & 1 & 25 & 15 & 36 & 0 & 0 & 213 \\
\hline & & & & & & & & & & & & & & & UMI & $\mathrm{AH}$ & 622 \\
\hline
\end{tabular}

Sumber: Hasil Pengolahan Data, Januari 2016

\section{Dimensi Inisiatif}

Tabel 9. Total Skor Dimensi Inisiatif

\begin{tabular}{|c|c|c|c|c|c|c|c|c|c|c|c|c|c|c|c|c|c|}
\hline \multirow{2}{*}{$\begin{array}{l}\text { PERNYAT } \\
\text { A- }\end{array}$} & \multirow[t]{2}{*}{ K D } & \multicolumn{5}{|c|}{$\mathrm{F}_{1}$} & \multirow{2}{*}{\multicolumn{5}{|c|}{$\mathrm{Xi}$}} & & & & \multirow{2}{*}{\multicolumn{2}{|c|}{ Fix X; }} & \multirow[t]{2}{*}{ L F; x X. } \\
\hline & & SS & $\mathrm{S}$ & $\mathrm{N}$ & $\begin{array}{l}\mathrm{T} \\
\mathrm{S}\end{array}$ & $\begin{array}{c}\text { ST } \\
\text { S }\end{array}$ & & & & & & & & & & & \\
\hline $\begin{array}{l}\text { Pegawai } \\
\text { berinisiatif } \\
\text { sendiri } \\
\text { dalam } \\
\text { menyelesai } \\
\text { kan suatu } \\
\text { pekerjaan }\end{array}$ & 19 & 4 & 9 & 19 & 1 & 0 & 5 & 4 & 3 & 2 & 1 & 20 & 11 & 57 & 2 & 0 & 195 \\
\hline $\begin{array}{l}\text { Pegawai } \\
\text { bekerja } \\
\text { sesuai } \\
\text { dengan } \\
\text { tupoksinya }\end{array}$ & 20 & 6 & 4 & 6 & 0 & 0 & 5 & 4 & 3 & 2 & 1 & 30 & 16 & 18 & 0 & 0 & 212 \\
\hline $\begin{array}{l}\text { Dalam } \\
\text { bekerj a } \\
\text { pegawai } \\
\text { selalu } \\
\text { bersemanga } \\
\mathrm{t}\end{array}$ & 21 & 16 & 3 & 4 & 0 & 0 & 5 & 4 & 3 & 2 & 1 & 80 & 13 & 12 & 0 & 0 & 224 \\
\hline
\end{tabular}

Sumber: Hasil Pengolahan Data, Januari 2016 


\section{Dimensi Kemampuan}

Tabel 10. Total Skor Dimensi Kemampuan

\begin{tabular}{|c|c|c|c|c|c|c|c|c|c|c|c|c|c|c|c|c|c|}
\hline \multirow{2}{*}{$\begin{array}{l}\text { PERNYATA } \\
-\end{array}$} & \multirow[b]{2}{*}{$\begin{array}{l}\text { K } \\
\text { D }\end{array}$} & \multicolumn{5}{|c|}{$\mathrm{F}$; } & \multirow{2}{*}{\multicolumn{5}{|c|}{$\mathrm{X}$; }} & \multirow{2}{*}{\multicolumn{5}{|c|}{ F;sX; }} & \multirow{2}{*}{$\mathrm{E}^{\mathrm{F}} \mathrm{X}$} \\
\hline & & SS & S & $\mathrm{N}$ & $\mathrm{T}$ & $\begin{array}{c}\text { ST } \\
\text { S }\end{array}$ & & & & & & & & & & & \\
\hline $\begin{array}{l}\text { organisasi } \\
\text { selalu } \\
\text { didahulukan } \\
\text { di atas }\end{array}$ & 2 & 6 & $\begin{array}{l}3 \\
1\end{array}$ & 14 & 2 & & 5 & 4 & 3 & 2 & 1 & 30 & $\begin{array}{r}12 \\
4\end{array}$ & 42 & 4 & 0 & 200 \\
\hline $\begin{array}{l}\text { Pimpinan } \\
\text { merupakan } \\
\text { sescorang } \\
\text { yang } \\
\text { dijadikan } \\
\text { panutan }\end{array}$ & 2 & 6 & $\begin{array}{l}4 \\
3\end{array}$ & 3 & 0 & & 5 & 4 & 3 & 2 & 1 & 30 & $\begin{array}{c}17 \\
2\end{array}$ & 9 & 0 & 1 & 212 \\
\hline $\begin{array}{l}\text { Kepentingan } \\
\text { organisasi } \\
\text { merupakan } \\
\text { prioritas } \\
\text { dalam }\end{array}$ & 2 & 9 & 4 & 4 & 0 & & 5 & 4 & 3 & 2 & 1 & 45 & $\sim$ & 12 & $0 \sim$ & 0 & 217 \\
\hline & & & & & & & & & & & & & & & JUI & & 629 \\
\hline
\end{tabular}

Sumber: Hasid Pengolahan Data, Januari 2016

\section{Dimensi Komunikasi}

Tabel 11. Total Skor Dimensi Komunikasi

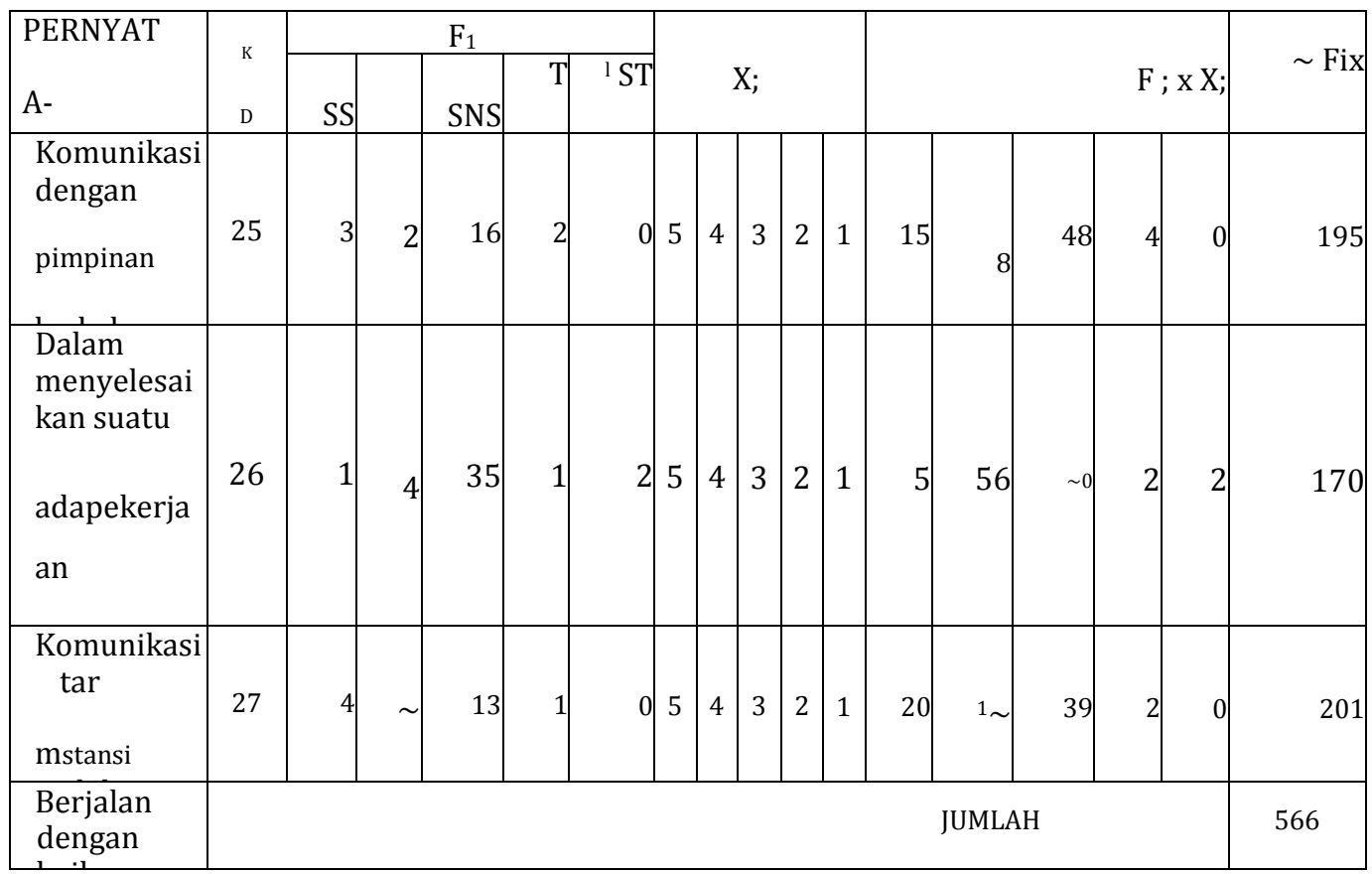

Sumber: Hash' Pengolahan Data, Januari 2016 


\section{Pengaruh Kepemimpinan transformasional $(X)$ terhadap Kinerja pegawai $(Y)$}

Berdasarkan hasil analisis uji kontribusi pengaruh, menunjukkan bahwa variabel kepemimpinan transformasional berpengaruh terhadap kinerja pegawai adalah sebesar 0.828 atau $82.8 \%$. Kepemimpinan transformasional yang terdiri dari aspek pengaruh yang ideal (idealized influence), aspek motivasi yang inspirasional (inspirational motivation), stimulasi intelektual (intellectual stimulation), dan pertimbangan yang bersifat individual (individualized consideration) berpengaruh cukup kuat terhadap kinerja pegawai yang terdiri dari dimensi kualitas kerja, ketepatan waktu, inisiatif, kemampaun dan komunikasi.

\section{Pengaruh Variabel lain (a) terhadap Kinerja pegawai (Y)}

Kepemimpinan transfonnasional yang terdiri dari yang terdiri dari aspek pengaruh yang ideal (idealized influence), aspek motivasi yang inspirasional (inspirational motivation), stimulasi intelektual (intellectual stimulation), dan pertimbangan yang bersifat individual (individuali, zed consideration) berpengaruh sangat kuat sebesar $82.8 \%$ terhadap kinerja pegawai yang terdiri dari dimensi kualitas kerja, ketepatan waktu, inisiatif, kemampaun dan komuniaksi sedangkan selebihnya yaitu sebesar $17.2 \%$ dipengaruhi oleh variabel lain yang tidak diteliti dalam penelitian ini.

Bahasan Pengaruh gaya kepemimpinan demokratsis terhadap kinerja pegawai di BPMPT Provinsi Jawa Barat. dimaksudkan untuk mengungkapkan dan menjelaskan basil penelitian serta menganalisis hasil penelitian dengan menggunakan pendekatan kuantitatif dan kualititatifjuga membahas pengujian hipotesis.

Berdasarkan basil perhitungan statistik dengan mepergunakan SPSS diperoleh bahwa variabel pengaruh gaya kepemimpinan transformasional terhadap kinerja pegawai sebesar koefisien detenninasi $\left(\mathrm{R}^{\prime}=82.8 \%\right.$ ) atau $82.8 \%$ Gaya kepemimpinan transformasional yang terdiri dari aspek pengaruh yang ideal $\left(\mathrm{X}_{1}\right)$, motivasi yang inspirasional $\left(\mathrm{X}_{2}\right)$, stimulasi intelektual (X3) serta pertimbangan yang bersifat individual (X4) yang berpengaruh cukup kuat terhadap kinerja pegawai yang terdiri dari aspek kualitas kerja, kuantitas kerja, kehandalan, sikap dan komunikasi.

Gaya kepemimpinan Transformasional secara persiai menunjukkan bahwa aspek pengaruh yang ideal berpengaruh terhadap kinerja pegawai adalah sebesar 0.065 atau Aspek pengaruh yang ideal ini terdiri dari indikator menunjukkan keyakinan diri yang kuat, menunjukkan nilai penting dan menumbuhkan kebanggan sedangkan kinerja diwakili oleh aspek kualitas kerja, ketepatan waktu, inisiatif, kemampuan dan komunikasi.

Berdasarkan basil pengamatan, aspek pengaruh yang ideal memberikan kontribusi terhadap kinerja pegawai. Dampaknya relatif kecil dibandingkan dengan yang lainnya, karena peneliti berpendampat bahwa basil keputusan bersama ini harus diimplementasikan dengan faktor lainnya. aspek pengaruh yang ideal ini akan mendorong para pegawai untuk berprestasi karena setiap pegawai diberikan keleluasaan untuk memberikan masukan.Pimpinan harus bisa memahami sasaran dan tujuan serta mampu pimpinan memberikan aspirasi kepada instansi terkait.

\section{Pembahasan Secara Parsial Pengaruh Aspek motivasi yang inspirasional $\left(X_{2}\right)$ terhadap Kinerja pegawai $(Y)$}

Berdasarkan pengolahan data menunjukkan bahwa aspek motivasi yang inspirasional berpengaruh terhadap kinerja pegawai adalah sebesar 0.210 atau $21.0 \%$. Aspek motivasi yang inspirasional terdiri dari indikator menginspirasi pegawai untuk mencapai kemungkinan yang tidak 
terbayangkan, menyelaraskan tujuan invidu dan organisasi serta menggunakan kata-kata untuk membnagikitkan semangat sedangkan kinerja diwakili olch aspek kualitas kerja, ketepatan waktu, inisiatif, kemampuan dan komunikasi.

\section{Pembahasan Secara Parsial Pengaruh Aspek Stimulasi intelektual (X3) terhadap Kinerja pegawai $(Y)$}

Berdasarkan pengolahan data menunjukkan bahwa aspek stimulasi intelektual berpengaruh terhadap kinerja pegawai. Aspek stimulasi intelektual ini terdiri dari indikator mendorong pemanfaatan imajinasi, mendorong penggunaan institusi yang diapdu dengan logika dan mengajak melihat perspektif barn sedangkan kinerja diwakili oleh aspek kualitas kerja, ketepatan waktu, inisiatif, kemampuan dan komunikasi. (Sedarmayanti, 2009)

\section{Pembahasan Secara Parsial Pengaruh Aspek Pertimbangan yang bersifat individual $\left(X_{4}\right)$ terhadap Kinerja pegawai (Y)}

Berdasarkan pengolahan data menunjukkan bahwa aspek pertimbangan yang bersifat individual berpengaruh terhadap kinerja pegawai. Aspek pertimbangan yang bersifat individual ini terdiri dari indikator mengidentifikasi kebutuhan individu, memberi kesempatan belajar dan memberdayakan bawahan sedangkan kinerja diwakili oleh aspek kualitas kerja, ketepatan waktu, inisiatif, kemampuan dan komunikasi. (Bass, 1994)

\section{8. $\quad$ Pengaruh Variabel Lain (e) terhadap Kinerja pegawai (Y)}

Berdasarkan uraian di atas, bahwa gaya kepemimpinan transformasional memiliki pengaruh erat dengan kincrja pegawai pada BPMPT Provinsi Jawa Barat. Berdasarkan hasil perhitungan data statistik diperoleh hasil bahwa variabcl kineija pegawai ternyata tidak hanya dipengaruhi oleh variabel gaya kepemimpinan transformasional semata tetapi ada variabel lain yang ikut mempengaruhi terhadap kinerja. Hal ini dalam istilah metodologi penelitian statistik diperoleh hasil bahwa dampak variabel lain ini tidak sebesar variabel gaya kempemimpinan transformasional, namun damapak variabel ini tidak dapat bisa diabaikan karena jika dioptirnalkan variabel ini akan mcnjadi pelengkap untuk meningkatkan kinerja pegawai.

\section{SIMPULAN}

Berdasarkan hasil penelitian dan pembahasan tentang Pengaruh Kepemimpinan Transformasional terhadap Kinerja Pegawai pada BPMPT Provinsi Jawa Barat. selanjutnya dapat disimpulkan hasil analisis dan pembahasan penelitian tersebut sebagai berikut:

Dampak secara simultan, kepemimpinan transformasional terhadap kincija pegawai pada BPMPT Provinsi Jawa Barat berpengaruh kuat. Dengan demikian, berdasarkan analisis menunjukan bahwa peningkatan kinerja pcgawai pada BPMPT Provinsi Jawa Barat. dipengaruhi oleh kepemimpinan dari kepalanya.

Dampak secara parsial, kinerja pegawai pada BPMPT Provinsi Jawa Barat. dapat dipengaruhi olch aspek pengaruh yang ideal (idealized influence), motivasi yang inspirasional (inspirational motivation), stimulasi intelektual (intellectual stimulation), dan pertimbangan yang bersifat individual (individualized consideration) memiliki pengaruh yang kuat dari variabel gaya kepemimpinan transformasional. Sedangkan pengaruh variabel yang tcrkecil terhadap kinerja adalah dari variabel lainnya. 


\section{DAFTAR REFERENSI}

Arikunto, Suharsimi. 2009. Prosedur Penelitian Suatu Pendekatan Praktik. Jakarta: PT. Rineka Cipta. Bass, B.M (1985) Leadership and Performance Beyond Expectations. New York:The Free Press Bass, B. M \& Avolio, B. J. (1994). Improving Organizational Effectiveness: Through Transformational Leadership. London: SAGE Publications TO.

Bass, B.M \& Riggio, R.E.(2006). Transformational Leadership. New Jersey: LEA. Publlihers Marwah.

Bass, B.M. (1990). Bass \& Stogdill's: Handbook of Leadership. Theory, Research \& Managerial Application.3rd Ed.New York:The Free Press:A Division of Macmillan, Inc Bryman, A. (1992). Charisma \& Leadership in Organizations. SAGE Publications, London. Newbury. New Delhi.

Bums, J. M. (1976). Leadership, Perennial, An imprint of Harper. Collins Publishers. www. harp erc o ll in s. com

Fathoni, Abdurahmat. 2009. Organisasi dan Manajemen Sumber Daya Manusia. Jakarta: PT. Rineka Cipta.

Flippo, Edwin B. 2009. Manajemen Personalia. Jakarta: PT. Erlangga.

Ghozali, Imam. 2005. Aplikasi Analisis Multivariate dengan Program SPSS. Semarang: Badan Penerbit Universitas Diponegoro.

Handoko, T. Hani. 2009. Manajemen Personalia dan Sumber Daya Manusia. Yogyakarta: BPFE UGM.

Koh,W.L., Srteers. R.M., \& Terborg J. R. (1995). The Effects of Transformational Leadership on Teacher Attitudes and Student Performance in Singapore. Abstract Journal of Organizational Bihavior, Vol.16, No 4. Diambil pada tanggal 9 Desember 2009, dari http://www.j stor.org/stable/2488561

Komariah, A. \& Tratna C. (2008). Visionary Leadership, Menuju Sekolah Efektif. Jakarta: PT. Bumi Aksara.

Kuhnert. (1994). Transactional and Transformational Leadership: A

Constructive/Developmental Analysis. Academy of Management Review, 12,648-657 Leithwood, K., Jantzi, D \& Steinbach, R. (1999). Changing Leadership for Changing Times,Philadelphia: Open University Press Buckingham.

Luthan, F. (1995). Organizational Behavior, McGraw- Hill International edition, Management and Organization Series. Seventh edition.

Mangkunegara, A.A. Anwar Prabu. 2009. Manajemen ,Sumber Dava Manusia Perusahaan. Bandung: PT. Remaja Rosdakarya.

Manning, T. T. (2002). Gender, Managerial, Transformational Leadership and Work Satisfaction. Women in Management Review, volume 17. Number 5.pp 207-216. Northouse, P. G. (2007). Leadership: Theory and Practice. London: SAGE Publications, International Education and Professional.

Rivai, Veitzal. 2009. Manajemen Sumber Daya Manusia Untuk Perusahaan: Dari Teori Ke Praktik. Jakarta: PT. Raja Grafindo Persada.

Robbins, S. P. (2001). Organizational Behavior, San Diego State University, Prentice Hall International, Inc.

Sedaryamanti. 2009. Sumber Daya Manusia dan Produktivitas Keija. Bandung: Mandar Maju. Sugiyono. 2010. Metode Penelitian Kuantitaif, Kualitatif dan R\&D. Bandung: Alfabeta.

2009. Statistika Untuk Penelitian. Bandung: Alfabeta.

Sunyoto, Agus. 2010. Manajemen Sumber Daya Manusia. Jakarta: STIE IPWI.

Thoha, Miftah. 2009. Perilaku Organisasi Konsep Dasar dan Aplikasinya. Jakarta: Raja Grafindo Persada.

Wuradji, M. S. (2008). The Educational Leadership, Kepemimpinan Transformational, Penerbit GAMA MEDIA Yogyakarta.

Yukl, Gary. (2006). Leadership in Organizational. Fifth Edition. New Jersey: Prentice Hall. Upper Saddle River, 07458.

94 Jurnal Kepariwisataan: Destinasi, Hospitalitas dan Perjalanan, Volume 2 Nomor 2, 2018: 84-94 